\title{
THE PROTOCOL TO A MEND THE CONVENTION ON OFFENCES AND CERTAIN ACTS COMMITTED ON BOARD AIRCRAFT: A MISSED OPPORTUNITY OR A SUFFICIENT MODERNIZATION?
}

\author{
JENNIFER A. URBAN*
}

\section{INTRODUCTION}

Aviation law has been highly publicized due to recent events, with coverage spanning from the missing Malaysian Airlines flight to passengers getting into a physical altercation over the use of a Knee Defender. ${ }^{1}$ It is easy for aviation law to become quickly complicated due to the many jurisdictions, each having their own national laws involved in every international flight. ${ }^{2}$ International treaties are known as one of the most efficient sources of air law to get many States to agree on how to solve the legal issues that continually arise with the expansion of global travel. ${ }^{3}$

There are four main types of unlawful acts that arise in aviation law: the hijacking of an aircraft; the impairment of an aircraft or its navigational capabilities while in flight; an attack to the aircraft while it is on the ground or at an airport; and unruly passengers. ${ }^{4}$ The Convention on Offences and Certain Other Acts Committed on Board Aircraft (Tokyo, 1963), hereinafter the Convention, was established to deal with the legalities of unruly passengers. ${ }^{5}$ Criminal unruly passenger acts can be done for many reasons including terrorism, money, political, mental instability, and alcohol or drug use. ${ }^{6}$ Commercial aircrafts have specifically been the target of many terrorist attacks due to the fact the global media gives vast amounts of attention to aviation disasters, along with the fact aircrafts are seen as a targeted national symbol and a symbol of power. ${ }^{7}$

* Jennifer Ann Urban is a Mississippi Licensed Attorney and LL.M. Candidate in Air and Space Law at the University of Mississippi School of Law. She earned her J.D., M.B.A., and B.A. at the University of Mississippi. Ms. Urban would like to thank Professor Jacqueline E. Serrao for her helpful insights and support.

1. See Bart Jansen, Mystery Still Unsolved Two Years After Malaysia Airlines 370 Vanished, USATODAY (Mar. 5, 2016, 1:28 AM), http://www.usatoday.com/story/news/2016/03/04/unsolvedmystery-of-mh370/81312864/ [https://perma.cc/NL2Q-FTL5]; Katia Hetter, Seat Recline Fight Diverts Another Flight, CNN (Sept. 3, 2014, 10:57 AM), http:/www.cnn.com/2014/08/26/travel/ united-flight-knee-defender/index.html [https://perma.cc/KMM7-HJQJ].

2. Jacqueline E. Serrao, Lecturer in Law, Univ. of Miss. Sch. of Law, Public International Aviation Law Course PowerPoint Presentation (Sept. 2014) [hereinafter Serrao, PowerPoint Presentation] (on file with author).

3. $I d$.

4. $I d$.

5. Convention on Offences and Certain Other Acts Committed on Board Aircraft, Sept. 14, 1963, 704 U.N.T.S. 10106 [hereinafter Tokyo Convention].

6. Serrao, PowerPoint Presentation, supra note 2.

7. $I d$. 
The hijacking and destruction of an aircraft is one of the most efficient ways to gain worldwide attention quickly for any message they are trying to get heard. ${ }^{8}$ Although smaller incidents may not seem as pressing as hijackings and weapons being brought on board, any required diversion can cause many issues such as the crews' unfamiliarity with the landing site and the costs and time lost from these diversions. ${ }^{9}$ In the United States, transportation makes up about twenty percent of the economy. ${ }^{10}$ The other eighty percent of the economy is significantly reliant on transportation as a stability factor, which is easily disrupted when a detrimental aviation event occurs, especially if it is international. ${ }^{11}$

In 1963, the Convention was an adequate legal authority for unruly passenger offences on aircrafts, but due to the modernization of the aviation industry and the increasing number of offences, the original Convention was in need of an update. This Article will address the rationale behind the need to amend the Convention, the views from those States and entities represented at the 2014 International Conference on Air Law in Montreal (hereinafter the Conference), the amendments that actually made it into the Protocol, and the question of whether the amendments went far enough or if this was a missed opportunity to identify and address problems within public international aviation law.

\section{History OF “Air LAW” AND THE TOKYO CONVENTION}

The beginning of international air law started with the 1910 Paris International Air Navigation Conference. ${ }^{12}$ Although no substantial results came from this conference, it was the first time diplomats met to attempt to create international air law navigation policies. ${ }^{13}$ One large issue that needed to be addressed was how airspace was owned by countries, therefore leading to principles of jurisdiction. ${ }^{14}$ The principle every State had sovereignty over the air space above its tangible territory was established in the Paris Convention of 1919, the first fundamental international air law. ${ }^{15}$ The Chicago Convention of 1944 is seen as the "Constitution" of international air law, as its principles have helped keep a basis of uniformity between the air law treaties. ${ }^{16}$ An example of the uniformity from the Chicago Convention is the term "aircraft" defined as "any machine that can derive support in the atmosphere from the reactions of the air other than the reactions of the air against the earth's surface," which is then used by the other treaties when developing policies regarding aircrafts. ${ }^{17}$
8. Id.
9. $I d$.
10. Id.
11. Id.
12. $I d$.
13. Id.
14. $I d$.
15. Id.
16. Id.
17. Id.; Chicago Convention on International Civil Aviation, Dec. 7, 1944, 15 U.N.T.S. 295 
Decades before the September 11, 2001 attacks, aircraft were hijacked and used in terrorist attacks. ${ }^{18}$ For example, the first recorded aircraft hijacking occurred in Peru on February 21, $1931 .{ }^{19}$ The hijacking of a Quebec Airways Flight in 1949 and the hijacking of the Continental Airlines Flight 11 on May 22, 1962 followed. ${ }^{20}$ These incidents signified an international issue that needed to be addressed..$^{21}$ According to the Preamble of the Convention, the reason for establishing the Treaty was to try and get States to work together in minimizing unruly behavior by passengers that risked the safety of everyone on board and the aircraft itself. ${ }^{22}$ The treaty helped to establish policies to maintain good order on aircrafts and if an unruly behavior offence were to occur, how it should be handled. ${ }^{23}$ The fact no penal laws applied to the international crimes created the problem of how an offender could be penalized for their actions, which the Convention helped solve by implementing appropriate laws for unruly passenger offences. ${ }^{24}$ It allowed for the State of Registry to use criminal jurisdiction for these offences. ${ }^{25}$ The Convention was also the first time in international law the Commander had the power to restrain anyone he or she believed was committing or about to commit an act that could jeopardize the safety of the people onboard. ${ }^{26}$ Only ten States ratified the Tokyo Convention in 1969, but now it is considered an element of general international law. ${ }^{27}$

Air law continued to grow through creation of the Convention for the Suppression of Unlawful Seizure of Aircraft (Hague Convention, 1970), the Convention for the Suppression of Unlawful Acts against the Safety of Civil Aviation (Montreal Convention, 1971), the Standards and Recommended Practices (SARPs) Annex 17 "Safeguarding International Civil Aviation Acts of Unlaw ful Interference" of 1974, the Protocol of the Suppression of Unlawful Acts of Violence at Airports Serving International Civil Aviation (Montreal Protocol, 1988), and the Convention of the Marking of Plastic Explosives for the Purpose of Detection (Montreal Convention 1991). ${ }^{28}$ Since the original Paris International Air Navigation Conference, many treaties have expanded aviation law. However, there is a pressing need to update and modernize these treaties due to the

[hereinafter Chicago Convention].

18. See, e.g., Serrao, PowerPoint Presentation, supra note 2.

19. First Hijack of an Aircraft, GuINNESS WORLD RECS., http://www.guinnessworldrecords. com/world-records/first-hijack-of-an-aircraft/ [https://perma.cc/3HM7-H9Z2] (last visited Mar. 30, 2016).

20. Id.

21. $I d$.

22. Tokyo Convention, supra note 5.

23. Id.

24. Serrao, PowerPoint Presentation, supra note 2.

25. $I d$.

26. $I d$.

27. Id.

28. Id. 
technological developments and the expansion of international travel by air. ${ }^{29}$ The Convention was one of the treaties that needed an extensive overhaul for it to be useful again in dealing with unruly passenger acts, which established the main purpose of the Protocol. ${ }^{30}$

\section{THE NEED FOR MODERNIZATION}

While the Convention implemented beneficial principles, the unruly behavior acts aboard aircrafts did not cease after its creation and have actually become an increasing threat. Not only did the hijackings and terrorist attacks by aircraft increase, but smaller unruly behavior offences have also become a rising problem within both domestic and international travel. ${ }^{31}$ Events ranged from the Ethiopian Airlines Flight 961 to the September 11, 2001 attacks to the shoe bomb plots. ${ }^{32}$ A few examples of smaller unruly behavior offences are the intoxicated Iceland Air Passenger who had to be duct taped to his seat and the most recent event of a disruptive emotional support pig and its owner being forcefully asked to disembark a US Airways flight. ${ }^{33}$ The Convention did not address many critical issues. It did not specify which acts were considered "criminal" or give a duty to extradite an unruly passenger. ${ }^{34}$ Also, the jurisdictional provisions left many gaps, such as not requiring a State with appropriate jurisdiction to exercise it and simply limiting the jurisdiction to the State of Registry. ${ }^{35}$

The International Air Transport Associations (IATA) described how the Convention was not a sufficient deterrent to unruly passenger acts and stated, "[t]he legal framework established by the Convention must be enhanced to allow law enforcement authorities adequate means to pursue offenders. A stronger legal framework that operators can rely upon would also have a strong deterrent effect." ${ }^{36}$ IATA used statistics from the Safety Trend Evaluation Analysis and Data Exchange System, hereinafter STEADS, to show the inefficiencies of the Convention. ${ }^{37}$ STEADS obtains data from 170 airlines around the world who

29. Id.

30. Id.

31. Id.

32. Id.

33. Id.; Alyssa Newcomb, Raging Airplane Passenger Duct Taped To Seat, ABC News (Jan. 5, 2013, 11:55 AM), http://abcnews.go.com/blogs/headlines/2013/01/raging-airplane-passengerduct-taped-to-seat/ [https://perma.cc/LSK6-WHEP]; Bill Keveney, When Pigs Fly? Not on This Plane, USA TODAY (Nov. 29, 2014, 8:14 PM), http://www.usatoday.com/story/news/nation/ 2014/11/29/passenger-leaves-flight-after-emotional-support-pig-is-disruptive/19662285/ [https://perma.cc/5F5J-DG3F].

34. Serrao, PowerPoint Presentation, supra note 2.

35. $I d$.

36. Int'1 Air Transp. Ass'n, The Views on Some Practical Aspects of the Issue of Unruly Passengers, at 4, DCTC Doc. No. 23 (Mar. 18, 2014), available at http://www.icao.int/Meetings/ AirLaw/Documents/DCTC_23_en.pdf [perma.cc/PA74-66B3].

37. Id. at 2 . 
submit periodic reports for data analysis. ${ }^{38}$ It is important to note because the studies are voluntary and not every international airline participates, the statistics cannot represent an overall industry-wide view. However, it does represent an adequate sample size. ${ }^{39}$

STEADS found the number of unruly passengers continues to increase. ${ }^{40}$ In 2010 , approximately one out of 1359 flights had an unruly passenger incident and this number increased in 2011 to one in every 1200 flights. ${ }^{41}$ Overall, from 2007 thru mid-2013 about one in every 1708 flights had an unruly passenger incident and out of those incidents, $20.9 \%$ had police intervention at the landing site. ${ }^{42}$ IATA had fifty airlines participate in its unruly passengers survey and every single participant had at least one unruly passenger incident within the past twelve months, while $43.40 \%$ of respondents had more than 100 incidents within that time period. ${ }^{43}$

The participants addressed the following factors associated with unruly passenger events (each percentage represents the percentage of respondents who identified this factor out of the overall pool of respondents):

- $96.23 \%$ verbal confrontations with crew or other passengers;

- $90.57 \%$ refusal to comply with crew instructions;

- $86.79 \%$ physical confrontations;

- $73.58 \%$ involved cigarettes;

- $71.70 \%$ threats to crew, other passengers, or the aircraft; and

- $60.38 \%$ sexual abuse or harassment. ${ }^{44}$

Alcohol was identified as the leading contributor to reported unruly passenger offences. ${ }^{45}$ Even with these factors, only approximately one third of the respondents turned over the events to police at the State of Landing. ${ }^{46}$ IATA also concluded unruly passenger offences occurred across the globe and not in one specific region. ${ }^{47}$

There was great support for amending the Tokyo Convention to fill the legal and technological gaps that had arisen. The Latin American Association of Aeronautical and Space Law (ALADA) stated the purpose of the Protocol to the Convention as "modernizing its text in order to adapt it to the evolution that passengers' behavior on board international flights have been showing during the last decades. ${ }^{, 48}$ The hope by most delegations was the Protocol would diminish
38. Id.
39. Id.
40. $I d$.
41. Id.
42. $I d$.
43. $I d$.
44. Id.
45. Id.
46. Id.
47. $I d$
48. Latin Am. Ass'n of Aeronautical \& Space Law, Comments on the Projected Protocol Text Submitted by the ICAO Legal Committee During its 35th Meeting Period, DCTC Doc. No. 11 
the amount of offences onboard international flights and there could be a more consistent approach applied for everyone involved to take, allowing these States to work together. ${ }^{49}$

\section{Everybody Gets a Say: The Views on Changes and Additions}

There were eighty-eight States ${ }^{50}$ eight international organizations, and one academic institution represented at the Conference, many of whom submitted working papers that included their thoughts on specific amendments to be included within the Protocol. ${ }^{51}$ Although many issues were addressed, the Convention analyzed three main areas: jurisdiction; in-flight officers; and a list of offences. ${ }^{52}$

The Note of the Secretariat created a non-exhaustive list of what it hoped the Convention would achieve:

- "[A] review of the jurisdictional clauses under the [Tokyo Convention] in order to align them with modern practice";

- "[T]he establishment of common standards and practices with regard to offences";

- "[T]he strengthening of international cooperation in harmonizing enforcement procedures";

- " $[T]$ he powers of the aircraft commander and related immunity"; and

- " $[\mathrm{T}]$ he status of In-Flight Security Officers.",53

$$
\text { A. Definition of "In Flight" }
$$

The Legal Committee proposed the term "In Flight" be defined in Article 1.3(a), of the Convention as,

$[A] n$ aircraft is considered to be in flight at any time from the moment when all its external doors are closed following embarkation until the moment when any such door is opened for disembarkation; in the case of a forced landing, the flight shall be deemed to continue until the competent authorities take over the responsibility for the aircraft and for

1 (Jan. 25, 2014), available at http://www.icao.int/Meetings/AirLaw/Documents/DCTC_11_en.pdf [perma.cc/8YBF-RHFP].

49. $I d$.

50. It is important to note that Ecuador's views were not added into this paper due to the content solely being in Spanish.

51. Int'l Conference on Air Law, Final Act of the International Conference on Air Law to Consider Amending the Convention on Offences and Certain Other Acts Committed on Board Aircraft, at 6-7, DCTC Doc. No. 36 (Apr. 3, 2014) [hereinafter Final Act], available at http://www. icao.int/Meetings/AirLaw/Documents/DCTC_36_en.PDF [perma.cc/UP95-CGZ3].

52. Serrao, PowerPoint Presentation, supra note 2.

53. Int'l Conference on Air Law, Note of the Secretariat, DCTC Doc. No. 4 (Jan. 22, 2014) [hereinafter Note of the Secretariat], available at http://www.icao.int/Meetings/AirLaw/Documents/ DCTC_04_en.pdf [perma.cc/K3NU-RWSY]. 
persons and property on board. ${ }^{54}$

ALADA and Argentina specifically supported the addition of this definition. ${ }^{55}$ IATA also supported the definition, reasoning that, "the temporal scope of the Convention should reflect the period during which the aircraft Commander's powers apply." 56 The changed definition would bring the Convention in unison with the 2010 Beijing Convention. ${ }^{57}$ Singapore argued if under the current Convention Article 5.2 was left in and the Protocol defined "in flight" within Article 1.3(a), there would be two different definitions for this term. ${ }^{58}$ It was suggested Article 5.2 be deleted within the Protocol. ${ }^{59}$ There were no real objections to this change and it was added into the Protocol as Article 1.3(a). ${ }^{60}$

\section{B. Jurisdictions}

The issue of jurisdictions for offences was a controversial topic discussed at the Conference. There were many different ideas presented on changing or replacing the existing jurisdiction, adding new jurisdictions, and if a State were eligible for jurisdiction over an offence, whether it was required to exercise it or just had the option to exercise it. There are five main State theories regarding jurisdictions for an offence committed onboard an aircraft. ${ }^{61}$

First, the territorial theory provides the State whose airspace the aircraft is in during the time of the offence will have jurisdiction in handling the prosecution of the offence. ${ }^{62}$ A problem with this theory is it can be difficult in some

54. Int'l Conference on Air Law, Draft Text of the Protocol to the Tokyo Convention of 1963 Proposed by the Legal Committee, DCTC Doc. No. 3 (July 9, 2013) [hereinafter Draft Text], available at http://www.icao.int/Meetings/AirLaw/Documents/DCTC_03_en.pdf [https://perma. $\mathrm{cc} / 4 \mathrm{FXP}-3 \mathrm{LTH}]$.

55. Latin Am. Ass'n of Aeronautical \& Space Law, supra note 48; Int'l Conference on Air Law, Diplomatic Conference To Adopt the Proposed Draft Text of the Protocol to the Tokyo Convention of 1963, DCTC Doc. No. 25 (Mar. 24, 2014) [hereinafter Diplomatic Conference], available at $\mathrm{http}: / /$ www.icao.int/Meetings/AirLaw/Documents/DCTC_25_en.pdf[perma.cc/9LH5BWA3].

56. Int'l Air Transp. Ass'n, Comments on the Issue of Temporal Scope, DCTC Doc. No. 21 (Mar. 13, 2014), available at http://www.icao.int/Meetings/AirLaw/Documents/DCTC_21_en.pdf [perma.cc/D6V6-396W].

57. Id. at 2 .

58. Int'l Conference on Air Law, Proposals for Amendments to the Draft Text-Definition of "In Flight", at 2, DCTC Flimsy No. 1 (Mar. 27, 2014) [hereinafter Proposals for Amendments], available at http://www.icao.int/Meetings/AirLaw/Documents/Flimsies/fl_01_en.pdf [perma.cc/ W2VM-B2P2].

59. Id. at 1 .

60. Protocol to Amend the Convention on Offences and Certain Other Acts Committed on Board Aircraft, Apr. 4, 2014, 2014 WL 1668702 [hereinafter Protocol], available at http://www. icao.int/Meetings/AirLaw/Documents/DCTC_34_en.PDF [perma.cc/D5UE-6FEW].

61. Serrao, PowerPoint Presentation, supra note 2.

62. Id. 
situations to determine exactly whose airspace the aircraft was in during the offence. ${ }^{63}$ The delegates at the Conference did not contemplate this theory.

Second, the national theory authorizes the State where the aircraft was registered to take jurisdiction over the offence, even if the offence occurs on the other side of the world than that State ${ }^{64}$ This jurisdiction was the one used within the original Convention. ${ }^{65}$

Third, the mixed theory combines the national theory and the territorial theory, giving both States the ability to exercise jurisdiction. ${ }^{66}$ This mixed theory was not used within the Protocol, but the mixtures of other types of jurisdictions were addressed at the Conference. ${ }^{67}$

Fourth, the State of Departure theory gives the State where the aircraft takes off jurisdiction over the offence.$^{68}$ Fifth, the State of Landing theory gives the State where the aircraft finally lands the ability to prosecute the offence. ${ }^{69}$ This theory was the most heavily debated at the Conference-one reason being the aircraft Commander has the ability to choose which States' law will apply by where he or she chooses to land. ${ }^{70}$ The Protocol included the State of Departure within the State of Landing jurisdiction. ${ }^{71}$

Qatar blatantly opposed all of the jurisdictions proposed because there were many gaps left open, the existing issues were left unresolved, and it only complicated matters further. ${ }^{72}$ Qatar proposed that there be much further analysis on this subject by the Legal Committee. ${ }^{73}$

1. State of Registration.-ALADA supported defining the State of Registration within the Protocol due to the commercial advancements in aviation, creating the need for distinct clarification. ${ }^{74}$ Singapore proposed that the State of Registration be the only jurisdiction that could exercise criminal jurisdiction, except for when the offence affected the Contracting State, there then should be national jurisdiction over the offence ${ }^{75}$ The security of the Contracting State was affected when the offence broke its laws regarding the flight or the maneuver of

63. Id.

64. Id.

65. Tokyo Convention, supra note 5, at 222.

66. Serrao, PowerPoint Presentation, supra note 2.

67. See Protocol, supra note 60.

68. Serrao, PowerPoint Presentation, supra note 2.

69. Id.

70. $I d$.

71. Protocol, supra note 60, at 3.

72. Int'l Conference on Air Law, Comments and Observations on the Draft Proposed Text of the Tokyo Protocol of 1963, DCTC Doc. No. 12 (Dec. 22, 2013) [hereinafter Comments and Observations], available at http://www.icao.int/Meetings/AirLaw/Documents/DCTC_12_en.pdf [perma.cc/88ZS-MN4K].

73. Id. at 2 .

74. Latin Am. Ass'n of Aeronautical \& Space Law, supra note 48, at 3.

75. Proposals for Amendments, supra note 58, at 1. 
the aircraft. ${ }^{76}$ The Contracting State could also be obligated to interfere due to a multilateral international agreement. ${ }^{77}$ Singapore's reasoning behind this proposal was it would simplify the jurisdictional overlap when the offence takes place in flight. ${ }^{78}$ The State of the Operator and the State of Landing jurisdictions were added to the Protocol as competent to exercise jurisdiction for offences occurring in flight, but Singapore's proposal was left out. ${ }^{79}$ In the Report of the Drafting Committee, the definition of the State of Registration was included, however, by the end of the Conference, the definition had also been removed. ${ }^{80}$

2. State of the Operator.-The special sub-committee agreed and was backed by support for the inclusion of the State of the Operator jurisdiction to be included in the Protocol. It was undecided whether this exercise of jurisdiction should be mandatory. ${ }^{81}$ ALADA approved of this jurisdiction being added because once combined with the State of Registration definition, it aligned with the modern use of commercial aircrafts. ${ }^{82}$ IATA fully supported the incorporation of the State of the Operator jurisdiction and insisted it be made mandatory, reasoning for the Convention to be fully updated it needed to incorporate the common, modern practice of leasing aircrafts. ${ }^{83}$ This modern practice means an airline, which leases an aircraft, is likely to have a stronger connection with the State of the Operator than with the State of Registration. ${ }^{84}$ The amount of airlines leasing their aircrafts increased by thirty-seven percent since $1980 .{ }^{85}$ IATA further explained that " $[t]$ he same or similar concept is employed in the Hague Convention 1970, the Montreal Convention 1971, the General Risks Convention 2009, the Unlawful Interference Compensation Convention 2009, the Beijing Convention 2010 and the Beijing Protocol 2010." ${ }^{86}$ Argentina followed IATA with its support, viewing the addition as just an update that had already been adopted by the international civil aviation legal field. ${ }^{87}$ Germany opposed the addition of the State of the Operator because it would be attached to a legal relationship, determined by civil law. Therefore, it would create more barriers to

76. $I d$.

77. Id.

78. Id. at 2 .

79. See Protocol, supra note 60 , at 3.

80. Int'l Conference on Air Law, Report of the Drafting Committee on Draft Protocol to Amend the Convention on Offences and Certain Other Acts Committed on Board Aircraft, DCTC Doc. No. 29 (Apr. 2, 2014) [hereinafter Report of the Drafting Committee], available at http://www.icao.int/Meetings/AirLaw/Documents/DCTC_29_en.pdf [perma.cc/GY2U-2VB4].

81. Note of the Secretariat, supra note 53, at 2.

82. Latin Am. Ass'n of Aeronautical \& Space Law, supra note 48, at 3.

83. Int'l Air. Transp. Ass'n, Comments on the Issue of State of Operator Jurisdiction, DCTC Doc. No. 18 (Mar. 13, 2014) [hereinafter IATA Doc. No. 18], available at http://www.icao.int/ Meetings/AirLaw/Documents/DCTC_18_en.pdf [perma.cc/PN7B-72LQ].

84. Id. at 1 .

85. Id.

86. Id. at 2 .

87. Diplomatic Conference, supra note 55, at 2. 
overcome. ${ }^{88}$

3. State of Landing.-The special sub-committee also agreed to include the State of Landing jurisdiction, with the support of many States and the support to make this jurisdiction mandatory. ${ }^{89}$ IATA heavily supported the addition of the mandatory State of Landing jurisdiction because it is one of the best ways to get more offences prosecuted. "In a survey conducted by IATA in 2013 . . more than 60 per cent of airlines reported that prosecutors at the place of landing cite lack of jurisdiction as a primary reason for not pursuing charges against an offender. ${ }^{, 00}$ Argentina also supported the addition of this jurisdiction because of its accessibility to evidence and the likelihood this jurisdiction would minimize the amount of offences that go without penalization. ${ }^{91}$ It also noted State of Landing as a mandatory jurisdiction has been included in other similar international treaties Argentina has ratified, "such as the Convention for the Suppression of Unlawful Seizure of Aircraft (The Hague, 1970), and the Convention for the Suppression of Unlawful Acts against the Safety of Civil Aviation (Montreal, 1971)."

Germany opposed the addition of State of Landing jurisdiction because the Commander could choose which State to land in and thus ultimately choose the forum for prosecution. ${ }^{93}$ Also, it argued that everyone involved will likely not all be from the same State or from the State of Landing; therefore, their ability to remain within the State of Landing is greatly limited, causing a prosecution problem. ${ }^{94}$ The German delegates further explained that under the State of Landing's laws, because of the proportionality doctrine, the State may not be able to arrest the unruly passenger or prosecute this offence, concluding that this would not aid in the amount of offences actually prosecuted or the efficiency of dealing with unruly passengers. ${ }^{95}$

The Jurisdiction Working Group ("Group") decided to clarify further when the State of Landing jurisdiction could be asserted, adding the following language into Article 3.2bis: "its next scheduled destination or the last place of departure. ${ }^{" 96}$ Also, the Group broadened the ability to exercise State of Landing

88. Int'l Conference on Air Law, Proposals for Amendments to the Reference Text, DCTC Doc. No. 8 (Jan. 16, 2014) [hereinafter Germany Doc. No. 8], available at http://www.icao.int/ Meetings/AirLaw/Documents/DCTC_08_en.pdf [perma.cc/8ZFN-VL68].

89. Note of the Secretariat, supra note 53, at 3.

90. Int'1 Air Transp. Ass'n, Comments on the Issue of State Landing Jurisdiction, DCTC Doc. No. 20 (Mar. 13, 2014) [hereinafter IATA Doc. No. 20], available at http://www.icao.int/Meetings/ AirLaw/Documents/DCTC_20_en.pdf [perma.cc/BTV6-H5V6].

91. Diplomatic Conference, supra note 55, at 2.

92. Id. (emphasis omitted).

93. Germany Doc. No. 8, supra note 88 , at 2 .

94. $I d$.

95. Id.

96. Int'1 Conference on Air Law, Jurisdiction Working Group: Drafting Proposals, DCTC Doc. No. 28 (Apr. 1, 2014) [hereinafter JWG Doc. No. 28], available at http://www.icao.int/ Meetings/AirLaw/Documents/DCTC_28_en.PDF [perma.cc/SG95-VU8K]. 
jurisdiction to when the safety of the aircraft, its passengers, and the property on board, along with good order and discipline, is jeopardized. ${ }^{97}$

4. State of an Involved National.-Originally, Article 3.1bis(c) of the Draft Text of the Protocol, added nationality as a new jurisdiction "when the offence or act is committed by or against a national of that State. ${ }^{98} \mathrm{New}$ Zealand asked for further explanation of this jurisdiction, but it does not look like an explanation was ever given and it was eventually removed in the Report of the Drafting Committee. ${ }^{99}$

Germany claimed it could accept this type of jurisdictional addition, but did not show a preference on whether it actually wanted the jurisdiction included. ${ }^{100}$ Argentina supported the inclusion of this type of jurisdiction, but only on an optional basis due to the fact that a State should not be forced to prosecute a crime only because the offender or victim was a national of that State. ${ }^{101}$

5. Additional Proposed Jurisdictions. - Germany proposed solely basing jurisdiction on contracting States and excluding all other types of jurisdictions, arguing States would more easily be able to decide between themselves and it does not need to be stated within the Convention. ${ }^{102}$ This proposal gained no other support. New Zealand and Turkey did, however, support the optional exercise of contracting States as written in Article 3bis. ${ }^{103}$

One delegation proposed including a territorial jurisdiction within the Protocol, but this was dismissed by the other members due to the fact that there had not been any real problems where this type of jurisdiction was needed.

6. Mandatory or Optional? - Germany disagreed the State of Landing and/or the State of the Operator should be mandatory because it did not want the jurisdiction provisions expanded. ${ }^{104}$ Germany argued that neither the State of Landing nor the State of the Operator was any more effective than the current jurisdiction of the State of Registration and that the addition of more jurisdictions only adds more confusion, unforeseeability of which jurisdiction the offender could be charged in, and more expenses for handling these offences. ${ }^{105}$ There was

97. Id. at 1 .

98. Draft Text, supra note 54, at 2 .

99. Int'1 Conference on Air Law, Diplomatic Conference (Montreal, 26 March to 4 April 2014) to Adopt the Proposed Text of the Protocol to the Tokyo Convention of 1963, DCTC Doc. No. 9 (Dec. 22, 2013) [hereinafter NZ Doc. No. 9], available at http://www.icao.int/Meetings/ AirLaw/Documents/DCTC_09_en.pdf [perma.cc/TJH8-WCQ8]; see Report of the Drafting Committee, supra note 80

100. Germany Doc. No. 8, supra note 88 , at 1.

101. Diplomatic Conference, supra note 55, at 3.

102. See Germany Doc. No. 8, supra note 88 , at 3.

103. NZ Doc. No. 9, supra note 99, at 2; Int'l Conference on Air Law, Legal Committee 35th Session Report, ICAO Doc. 10014-LC/35 (May 15, 2013) [hereinafter Legal Committee 35th Session Report], available at http://www.icao.int/Meetings/AirLaw/Documents/Reference/10014 en.pdf [https://perma.cc/4N2Q-E33Z].].

104. Germany Doc. No. 8, supra note 88 , at 2.

105. Id. 
no enforcement gap that the German delegates could see, so there was no need for more enforcement jurisdictions. ${ }^{106}$ However, Germany stated it could possibly accept the State of Landing and State of the Operator being included if they were only done on an optional basis. ${ }^{107}$ It also stated that the wording "is competent" in regards to the jurisdictions in Article 3, leads to confusions on whether the exercise of jurisdiction is mandatory or optional. ${ }^{108}$

IATA supported mandatory jurisdictions for both the State of Landing and the State of the Operator because many States left these types of crimes unpunished. ${ }^{109}$ The offences were likely unpunished because of the lack of domestic laws regarding unruly passenger offences and the need for an international treaty to give authority to prosecute. ${ }^{110}$ Mandatory jurisdiction would give a specific standard for the international community, thus alleviating the mess of dealing with domestic laws or the lack thereof. ${ }^{111}$ According to IATA's statistics, most airlines agreed domestic offences, where the State of Landing was also where the airline was based, were handled properly. ${ }^{12}$ Most international incidents with foreign airports, however, were rarely handled properly, if handled at all, due to the varying penalties across the globe and the inability of the crewmembers to be able to stay in the foreign State for the prosecution. ${ }^{113}$ In these foreign incidents, it was highly unlikely for a State to prosecute or impose a penalty unless there was been a physical assault or injury. ${ }^{114}$

The Legal Committee concluded that the overall majority of States were in favor of the addition of the State of Landing and the State of the Operator to strengthen the authority of the Convention. ${ }^{115}$ The Legal Report did, however, take note of the obvious split on the issue of mandatory or optional jurisdictions. ${ }^{116}$

Many States supported the mandatory State of Landing jurisdiction mainly because it would help ensure unruly passenger offences would be prosecuted and hopefully punished, therefore closing the "jurisdictional" or "enforcement" gap. ${ }^{117}$ The opponents of the mandatory State of Landing argued that there would still be the uncertainty as to which law overall should be applied considering certain behaviors were punishable in one State but not in another. ${ }^{118}$ Also, one delegation

106. Id

107. Id. at 3 .

108. Id.

109. IATA Doc. No. 18, supra note 83; IATA Doc. No. 20, supra note 90, at 1 .

110. IATA Doc. No. 20, supra note 90 , at 1.

111. Id. at 2 .

112. Int'l Air Transp. Ass'n, supra note 36, at 3.

113. Id.

114. Id.

115. Legal Committee 35th Session Report, supra note 103.

116. Id.

117. Id. at 2-3.

118. Id. 
opposed to the mandatory jurisdiction brought up the fact some States may not be able to afford to have this mandatory jurisdiction imposed on them. ${ }^{119}$ Due to the confusion of what mandatory and optional would actually mean,

$[\mathrm{t}]$ he Secretary clarified that mandatory jurisdiction would require a State to have legislation empowering it to take jurisdiction, whereas optional jurisdiction would give a State discretion whether or not to enact legislation to take jurisdiction. Whether mandatory or not, those States with a State of landing jurisdiction can always elect not to prosecute any particular case. ${ }^{120}$

The Legal Committee decided the State of Landing jurisdiction was to be written as mandatory within the Draft Protocol, but the wording of the final Protocol still allows uncertainty of the obligations under this issue. ${ }^{121}$

A Working Group was also established to help solve the unanswered issues from the new mandatory State of Landing jurisdiction. ${ }^{122}$ One of the biggest issues was whether a State of Landing should still have mandatory jurisdiction when the flight was not scheduled to land there, but had to due to an emergency diversion. ${ }^{123}$ This led to the Group's first concern of addressing the issue of legal certainty, meaning whether passengers would be able to anticipate what State's criminal laws passengers they would be charged under if they committed an offence and how a diversion may affect this perception. ${ }^{124}$ The Group proposed two solutions. ${ }^{125}$ First, the mandatory State of Landing jurisdiction would not apply if the landing was unplanned unless the "the diversion was made by the commander of the aircraft because [sic] an incident to which mandatory jurisdiction would normally apply," such as due to technical problems or bad weather. ${ }^{126}$ This proposal potentially further complicated matters regarding what a "normal diversion" might be. Second, the Group proposed limiting the scope of offences for the mandatory State of Landing jurisdiction to those that directly affected the safety of the aircraft and its passengers while not requiring mandatory jurisdiction for offences that did not concern the safety of the flight. ${ }^{127}$ The second proposal was implemented in the Protocol. ${ }^{128}$

The next issue addressed by the Group was about proportionality in regards

119. Id. at 2-4.

120. Id.

121. Id.

122. Int'l Conference on Air Law, Report of the Working Group on Jurisdiction, at 1, DCTC Flimsy No. 2 (Mar. 31, 2014) [hereinafter Jurisdiction Report], available at http://www.icao.int/ Meetings/AirLaw/Documents/Flimsies/fl_02_en.pdf [perma.cc//MEP9-465R].

123. Id.

124. Id.

125. Id.

126. Id. at 2 .

127. Id.

128. Protocol, supra note 60 , at 3. 
to the mandatory State of Landing jurisdiction. ${ }^{129}$ The Group first considered establishing a severity standard to decide which offences could be used for mandatory jurisdiction. ${ }^{130}$ This solution failed because of the varying penalties from State to State, not allowing for the creation of a uniform severity system. ${ }^{131}$ Extradition and dual-criminality were also considered, however, these solutions also failed due to the burden they would impose on the States to know every other States' laws and extradition policies. ${ }^{132}$ Extradition by the mandatory State of Landing jurisdiction was also seen as too extreme for small offences. ${ }^{133} \mathrm{~A}$ third solution was proposed as a different form of severity test where the mandatory State of Landing jurisdiction would only apply if the aircraft Commander had properly delivered the offender under Article 9.1. ${ }^{134}$ This meant that the test would be whether the aircraft Commander understood the offence to be severe enough to take the action of delivering the offender to authorities. ${ }^{135}$ The Commander's actions would show his or her true opinion regarding whether the offence was severe enough for this mandatory jurisdiction to kick in. ${ }^{136}$ These proposed solutions were combined into a three-part test:

a State is required to establish jurisdiction if an incident has occurred on the aircraft that lands in its territory, as long as that incident affects the safety and good order of the aircraft and the people on it, and the Commander has taken the step of delivering the passenger concerned to the authorities, which he or she is only empowered by the Convention to do if of the opinion that a serious offence has been committed. ${ }^{137}$

The reasoning behind the establishment of this test was that it made the mandatory jurisdiction proportional to the offence committed, meaning mandatory jurisdiction would be required when the offence was serious enough to endanger the safety of the aircraft. ${ }^{138}$ It also allowed the potential offender the opportunity to understand if his or her actions endangered others, he or she could be subject to any State's mandatory jurisdiction where the aircraft may be forced to land.

The majority of delegations also supported the State of the Operator being included as a mandatory jurisdiction. ${ }^{139}$ The main reasoning behind this support was because it addressed the extremely common situation of leasing aircrafts

129. Jurisdiction Report, supra note 122, at 2.

130. Id. at 3 .

131. Id.

132. $I d$.

133. $I d$.

134. $I d$.

135. Id.

136. $I d$.

137. Id. at 4.

138. Id.

139. Legal Committee 35th Session Report, supra note 103, at 2-5. 
within today's aviation industry that was not an issue back in $1963 .{ }^{140}$ The opposition to making this jurisdiction mandatory was the State of the Operator jurisdiction was not as obvious as the State of Landing mandatory jurisdiction, potentially causing confusion. ${ }^{141}$

The State of Involved Nationals had great support as being listed as an optional jurisdiction. ${ }^{142}$ After one delegation pointed out Article 3.3 encompassed all optional jurisdictions, including that of an involved national, the Legal Committee decided to leave out the specific reference of this jurisdiction within the Protocol. ${ }^{143}$

It is important to note the wording in the Articles of the Protocol that address jurisdiction. The word "competent" is used rather than mandatory or optional, which means that the States listed have the "right" to exercise jurisdiction, but if a State is not "competent" to do so, it is not required. ${ }^{144}$ However, if the State is "competent" to exert jurisdiction, the Protocol pushes an obligation onto that State to do so. ${ }^{145}$

\section{Discrimination, Double Jeopardy, and Due Process}

As with any convention, many of the issues built upon each other and then overlapped. The jurisdiction issues brought about the concerns of double jeopardy and due process. ${ }^{146}$ The Draft Text of the Protocol added Article 3bis:

If a Contracting State, exercising its jurisdiction under Article 3, has been notified or has otherwise learned that one or more other Contracting States are conducting an investigation, prosecution or judicial proceeding in respect of the same offences or acts, that Contracting State [may]/ [shall], as appropriate, consult those other Contracting States with a view to coordinating their actions. ${ }^{147}$

The Group in its Drafting Proposals decided that the obligations under this addition needed to be mandatory; therefore, the word "shall" was used. ${ }^{148}$ In its Report, the Group explained that although increasing the amount of jurisdictions that could possibly be involved in an unruly passenger incident, there was also an increase in the risk of potentially having double jeopardy through multiple States trying the person more than once for the same offence. ${ }^{149}$ New Zealand

140. $I d$.

141. Id.

142. Id. at 2-6.

143. Id.

144. E-mail from Jacqueline Serrao, Lecturer in Law, Univ. of Miss. Sch. of Law, to Jennifer Urban, Law Student, Univ. of Miss. Sch. of Law (Nov. 17, 2014, 1:05 PM) (on file with author).

145. Id.

146. Jurisdiction Report, supra note 122 , at 4.

147. Draft Text, supra note 54.

148. JWG Doc. No. 28, supra note 96, at 2.

149. Jurisdiction Report, supra note 122, at 4. 
suggested making the obligation optional within Article 3 bis so this responsibility was up to the State. ${ }^{150}$ It reasoned Article 3 bis was key in minimizing the overlap of work by multiple States and it prevented double jeopardy throughout multiple jurisdictions. ${ }^{151}$ The Legal Committee also supported the addition, but in a mandatory capacity, as it allowed for better coordination within the multiple different jurisdictions legal systems. ${ }^{152}$ The Legal Committee's Report identified support for the inclusion of Article 3 bis from many delegations. ${ }^{153}$ Article 3 bis was included in the Protocol as a mandatory obligation to minimize overlap between the involved jurisdictions. ${ }^{154}$

The Working Committee on Jurisdiction also proposed adding another, more specific amendment to explain the issue of double jeopardy further. Although the more specific provision was never adopted by the Convention, a similar, more concise version was added. ${ }^{155}$ This amendment was included as Article 17.2, explicitly requiring that each Contracting State, when acting within obligations under the Convention, had to respect the doctrines of due process and fair treatment. ${ }^{156}$

Similarly, with more jurisdictions potentially involved in each incident, the issue of discrimination arose. The Working Group on Jurisdiction wanted to expand the anti-discrimination policies under the Treaty. ${ }^{157}$ This suggestion was added in as Article 2 in the Protocol and it banned discrimination "on any grounds." 158

\section{In-Flight Security Officers}

In-Flight Security Officers (ISFOs) were a large topic of debate during the Convention. ${ }^{159}$ The Note of the Secretariat identified that IFSOs had not been an issue when the Convention was originally ratified, but that due to the Legal Committee's not being able to come to a consensus on the matter, further legal analysis needed to be done on the idea of IFSOs. ${ }^{160}$ The Friends of the Chair W orking Group was created to aid in defining the details of the following policies regarding IFSOs:

a) IFSOs are to be included in a separate and special group which reflected the status quo;

b) the definition of IFSO should be as close as possible to the

150. NZ Doc. No. 9, supra note 99 , at 2.

151. Id.

152. Legal Committee 35th Session Report, supra note 103, at 2-6.

153. Id.

154. Protocol, supra note 60 , at 4.

155. Id. at 6 .

156. Id.

157. Jurisdiction Report, supra note 122 , at 5.

158. Protocol, supra note 60 , at 3.

159. See Legal Committee 35th Session Report, supra note 103, at 2-9, 2-13.

160. Note of the Secretariat, supra note 53, at 2. 
definition in Annex 17 to the Chicago Convention;

c) the scope of functions of IFSOs with respect to unlawful interference should be narrowed;

d) IFSOs should be involved in the safety of aircraft and passengers on board;

e) States should be able to authorize their IFSOs to respond to threats to good order and discipline on board; and

f) IFSOs should have at least the protection given to passengers on board. ${ }^{161}$

The Air Navigation Bureau was then solicited to help address the potential impacts of IFSOs onboard aircrafts, so it helped draft two options for Article 6 while indicating the second option was the better choice. ${ }^{162}$ The Draft Text of the Protocol added a definition of IFSOs, ${ }^{163}$ which was included in the Protocol. In the draft of Article 6 there were the two options for IFSOs to be included. ${ }^{164}$ The first option in Article 6 stated,

1. The aircraft Commander or in-flight security officer may, when he or she has reasonable grounds to believe that a person has committed, or is about to commit, on board the aircraft, an offence or act contemplated in Article 1, paragraph 1, impose upon such person reasonable measures including restraint which are necessary:

a) to protect the safety of the aircraft, or of persons or property therein; or

b) to maintain good order and discipline on board; or

c) to enable the aircraft commander to deliver such person to competent authorities or to disembark him in accordance with the provisions of this Chapter.

2. The aircraft commander may require or authorize the assistance of other crew members and may request or authorize, but not require, the assistance of passengers to restrain any person whom he is entitled to restrain. Any crew member or passenger may also take reasonable preventive measures without such authorization when he has reasonable grounds to believe that such action is immediately necessary to protect the safety of the aircraft, or of persons or property therein. ${ }^{165}$

The second option in Article 6 took IFSOs out of the first section and added them

161. Legal Committee 35th Session Report, supra note 103, at 2-71.

162. Int'l Conference on Air Law, The Views of Air Navigation Bureau, ICAO on Article VI of the Draft Protocol to Amend the Tokyo Convention, at 1-2, DCTC Doc. No. 5 (Jan. 20, 2014) [hereinafter ANB Doc. No. 5], available at http://www.icao.int/Meetings/AirLaw/Documents/ DCTC_05_en.pdf [perma.cc/CL9K-5BTK].

163. Draft Text, supra note 54, at 1 .

164. $I d$. at $2-3$.

165. Id. 
into the second section in the second sentence after the words "crew member."166 The Air Navigation Bureau reasoned Option Two was a better choice because it did not allow for IFSOs to be put on the same level or give them as much responsibility as the aircraft Commander. ${ }^{167}$ It was further reasoned that the Commander should be able to have the final authority that cannot be weakened or shared with anyone else, especially due to the fact that the Commander is more knowledgeable about the safety of the aircraft. ${ }^{168}$ Also, the IF SOs might be jaded by their duties given by the State that they work for, therefore potentially creating a conflict between the IFSO and the Commander, weakening the safety of the aircraft. ${ }^{169}$

The United States was a strong proponent of Option One in Article 6, arguing the Convention predated the IFSO programs that had been developed as solutions to help curb the increase in threats within international aviation. ${ }^{170}$ IFSOs are a necessity to help address the issue of terrorism, especially flights that are in anyway connected to the United States. ${ }^{171}$ The United States defined IFSOs as, "government personnel who are specially trained and selected and deployed on aircraft with the purpose of protecting that aircraft and its occupants." forty States have IFSOs and the International Civil Aviation Organization (ICAO) has recognized IFSOs. ${ }^{173}$ The United States did not suggest requiring States to have IFSO programs, but did want the States that do have these programs to be able to use their IFSOs adequately. ${ }^{174}$

The United States contended accepting Option One and giving IFSOs more power would lead to better handling of unruly passenger offences. ${ }^{175}$ IFSO should not have to gain authorization from the Commander before acting and the IFSO may be better situated to handle the problem in the passenger cabin, while the Commander needs to stay inside the cockpit. ${ }^{176}$ According to the United States, this power to act without authorization in no way takes away from the Commander's control over the aircraft, but instead allows for the best handling of the situation. ${ }^{177}$ Currently, IFSOs have the same authority as passengers and they are not protected from liability for their actions to maintain order and

166. Id. at 3 .

167. ANB Doc. No. 5, supra note 162 , at 2 .

168. Id.

169. Id.

170. Int'l Conference on Air Law, Authority and Protections for In-Flight Security Officers, at 1, DCTC Doc. No. 7 (Jan. 23, 2014) [hereinafter U.S. Doc. No. 7], available at http://www.icao. int/Meetings/AirLaw/Documents/DCTC_07_en.pdf [perma.cc/S9SU-R9R5].

171. $I d$.

172. Id.

173. Id.

174. Id. at 4.

175. Id.

176. Id.

177. $I d$. at 2 . 
discipline unless directed by the Commander. ${ }^{178}$ This leads to no protection of the IFSOs for acting within their official duties from their governments. ${ }^{179} \mathrm{By}$ adopting Option One, the United States contended that it would create a separate class for IFSOs, giving them separate authority to act. ${ }^{180}$ IFSOs need to be able to take action as early as possible without having to wait for a bad situation to develop, which reinforced the main function of the convention: to protect persons onboard international flights. ${ }^{181}$ The earliest stage of interference with an unruly behavior offence is key for safety and there are many times when it is not plausible for the IFSO first to get permission to take action from the Commander. ${ }^{182}$ The United States argued that Option Two did not give the IFSOs any new authority and actually appeared to decrease the authority they did have due to not clarifying whether the Commander could request the IFSOs assistance with an incident. ${ }^{183}$ Although better clarification was made when Option Two was chosen for the Final Protocol, it still did not allow for the power the United States claimed the IFSOs needed. ${ }^{184}$

ALADA also supported Option One of Article 6, but did address modifications ALADA believed needed to be made prior to adoption. ${ }^{185}$ It proposed IFSOs should have the same level of authority as the Commander during the specific moment of the IFSO's actions, but as soon as the Commander gains knowledge about the incident he will be the one to decide what steps should be taken next. ${ }^{186}$ The reasoning behind this proposal was the IFSO will likely notice things in the cabin the crew and Commander will not, so by acting as a surveillance system, IFSOs would be able to take quick action before more danger could occur. ${ }^{187}$ ALADA stated, "[t]he appropriate action of the [IFSO] will thus be highly effective in preventing and avoiding the danger as he has been adequately trained to act quicker than the Commander, who is in the cockpit complying with his duties and several minutes can pass before he can take pertinent action." ${ }^{, 188}$ Other States and organizations also supported that statement as a main reason for IFSO inclusion in the Protocol. ${ }^{189}$ ALADA also stated Annex 17 of the Chicago Convention had incorporated IFSOs and explained in order to

178. Id. at 3 .

179. See id.

180. Id.

181. Id. at 4 .

182. Id.

183. Id. at 3 .

184. See generally Protocol, supra note 60.

185. Latin Am. Ass'n of Aeronautical \& Space Law, supra note 48, at 3.

186. Id.

187. Id. at 2 .

188. Id.

189. See Int'l Conference on Air Law, Amendment to Article 10 of the Tokyo Convention 1963, at 3-4, DCTC Doc. No. 15 (Feb. 28, 2014) [hereinafter Amendment to Article 10], available at http://www.icao.int/Meetings/AirLaw/Documents/DCTC_15_en.pdf [perma.cc/9UM5-CKSH]. 
not be contradictory, the Protocol also needed to incorporate IFSOs. ${ }^{190}$ ALADA finally proposed instead of an IFSO solely being affiliated with a specific State's government, he or she should also be affiliated with airlines or airports. ${ }^{191}$ This proposal was not included within the Protocol. ${ }^{192}$

Turkey supported Option One and suggested property be included in what the IFSO can take actions to protect. ${ }^{193} \mathrm{New}$ Zealand also proposed property be included within the definition of IFSOs. ${ }^{194}$ Property was never included in the Protocol as a specified element the IFSO could take action to prevent. ${ }^{195}$ Although the Protocol chose Option Two, it did include the wording, suggested by Turkey, "bilateral and multilateral agreements" in its final provisions. ${ }^{196}$

New Zealand supported Option Two due to the fear of potential disagreements between IFSOs and the Commander, possibly leading to an increase in safety concerns. ${ }^{197}$ In regards to these concerns, the Philippines suggested the term "with the assistance of the in-flight security officer" be added to show the chain of command. ${ }^{198}$ Neither potential disagreements nor the chain of command was included in the Protocol. ${ }^{199}$ Indonesia also supported Option Two for the same reasoning and suggested wording be added to clarify the aircraft Commander had complete authority the entire time the plane was "in flight." 200

Japan supported the second option due to not having seen any need for IFSOs to have equal authority with Commanders in the past. ${ }^{201}$ Japan believed Option Two was a sufficient legal basis for IFSOs to complete duties for the safety of the

190. Latin Am. Ass'n of Aeronautical \& Space Law, supra note 48, at 2.

191. Id.

192. See Protocol, supra note 60 , at 4 .

193. See Int'l Conference on Air Law, Comments for New Proposals on Tokyo Convention, DCTC Doc. No. 14 (Feb. 26, 2014) [hereinafter Comments for New Proposals], available at http://www.icao.int/Meetings/AirLaw/Documents/DCTC_14_en.pdf [perma.cc/82YL-95LG].

194. See NZ Doc. No. 9, supra note 99, at 1.

195. See Protocol, supra note 60, at 4.

196. Id.; Comments for New Proposals, supra note 193, at 1.

197. NZ Doc. No. 9, supra note 99, at 2.

198. Int'l Conference on Air Law, Comments and Proposal to the Proposed Draft Text of the Protocol to the Tokyo Convention of 1963, DCTC Doc. No. 16 (Mar. 4, 2014) [hereinafter Philippines Doc. No. 16], available at http://www.icao.int/Meetings/AirLaw/Documents/DCTC 16 en.pdf [perma.cc/QS42-KQ7B].

199. See Protocol, supra note 60, at 4 .

200. Int'l Conference on Air Law, Authority in Handling Offences and Certain Other Acts Committed On Board Aircraft, DCTC Doc. No. 24 (Mar. 21, 2014) [hereinafter Authority in Handling Offences], available at http://www.icao.int/Meetings/AirLaw/Documents/DCTC_24_en. pdf [perma.cc/3YNT-QR2F].

201. Int'l Conference on Air Law, Comments on the Draft Text of the Protocol to the Tokyo Convention of 1963, at 1-2, DCTC Doc. No. 10 (Jan. 31, 2014) [hereinafter Japan Doc. No. 10], available at http://www.icao.int/Meetings/AirLaw/Documents/DCTC_10_en.pdf[perma.cc/25DUASHU]. 
plane. ${ }^{202}$ It was proposed the Protocol define a limited scope for IFSO action, where he or she could only take action in very serious offences. ${ }^{203}$ Japan stated that if IFSOs were to deal with smaller offences, their identities would be known, therefore not allowing them to be able to handle more serious threats properly. ${ }^{204}$ This limited scope was not included in the Protocol. ${ }^{205}$

Argentina was a proponent of Option Two and supported adding terminology in regards to IFSOs. ${ }^{206}$ It stated approximately forty States, which make up the majority of international civil air traffic, have IFSO programs, so these programs cannot simply be ignored by the Protocol. ${ }^{207}$ The reason for its support of the second option was due to the first option allowing the overlap of authority and because the Commander has the most knowledge about his or her aircraft and he or she is ultimately responsible for the safety of the aircraft. ${ }^{208}$ Under Article 10, Argentina argued IFSOs should not be given full immunity, but instead there should be reasonable legal protection for their actions to protect and ensure the safety of the aircraft, along with the persons onboard. ${ }^{209}$ Argentina raised the critical issue of what happens when an unsuspecting third-party State, such as an emergency landing State, is involved with an unruly passenger event also involving an IFSO. ${ }^{210}$ If the Protocol chose to exclude IFSOs and their use was simply left up to bilateral and multilateral agreements, it would remain unclear how the third-party State should handle this situation; therefore, the Protocol was the perfect place to solve this issue that would inevitably arise under the modernized Convention. ${ }^{211}$ Although not specifically aimed at solving this issue, Articles 6.3 and 6.4 of the Protocol set new policies that laid out the proper way for the third-party State to handle these situations. ${ }^{212}$

Even though it did not outright choose one of the two options for Article 6, the Report of the Friends of the Chair on IF SO Provisions' arguments seemed to lean towards supporting the second option. ${ }^{213}$ This group did want the IFSO in a separate section than that of the aircraft Commander and anyone else onboard. ${ }^{214}$ It argued IFSOs under bilateral and multilateral agreements should be allowed to take reasonable preventive action when immediately necessary to protect the

202. Id. at 2 .

203. Id.

204. Id. at 1.

205. See Protocol, supra note 60 , at 4 .

206. Diplomatic Conference, supra note 55, at 4.

207. Id. at 3 .

208. Id.

209. Id. at 4 .

210. Id.

211. See id.

212. See Protocol, supra note 60 , at 4.

213. See Int'l Conference on Air Law, Report of the Friends of the Chair on In-Flight Security Officer Provisions, DCTC Doc. No. 31 (Apr. 4, 2014), available at http://www.icao.int/Meetings/ AirLaw/Documents/DCTC_31_en.pdf [perma.cc/3K62-VNEJ].

214. Id. 
aircraft and the persons onboard. ${ }^{215}$ The group also wanted Article 10 of the Protocol essentially to give full immunity to anyone, including IFSOs, who had to take actions against the unruly passenger. ${ }^{216}$

Qatar opposed any inclusion of IFSOs in the Protocol and instead suggested IFSOs be left to multilateral agreements between ICAO members. ${ }^{217}$ The basis of its opposition was all States would then have to implement an IFSO program and this burden should not be imposed on States who do not want IFSOs included in the Protocol. ${ }^{218}$ Also, Qatar emphasized any weapon aboard an aircraft and the potential for disputes between IFSOs and Commanders jeopardizes the overall safety of that aircraft. ${ }^{219}$

The Legal Committee Report mentioned many States wanted IFSOs to be explicitly recognized within the Protocol, as they have previously been referenced within Annex 17 of the Convention on International Civil Aviation and the Security Manual for Safeguarding Acts of Unlawful Interference. ${ }^{220}$ The key reasoning behind the inclusion of IFSOs was that they did not fit into the category of crew or passengers; therefore their role in regards to interactions with the aircraft Commander and their legal protection needed to be addressed. ${ }^{221}$ Several of these States wanted IFSOs to be able to intervene when an act of unlawful interference occurred, but not just to maintain good order and discipline on the aircraft. ${ }^{222}$ The majority voted in favor of adding Option Two because the option gave the Commander full authority and this option fit best with the previous international policies addressing IFSOs. ${ }^{223}$ It was suggested that each State should be allowed to establish the duties and responsibilities of their IFSOs and that the deployment of IFSOs should depend on bilateral or multilateral agreements. ${ }^{224}$ The determined purpose of the IFSOs was "protecting that aircraft and its occupants against acts of unlawful interference." 225 After much analysis, the Protocol added in Option Two for Article 6 and included IFSOs, along with the rest of the persons onboard, in Article 10 regarding legal protection for their actions against unruly passengers. ${ }^{226}$

\section{E. List of Offences}

The list of offences was one of the most critically analyzed and intensely

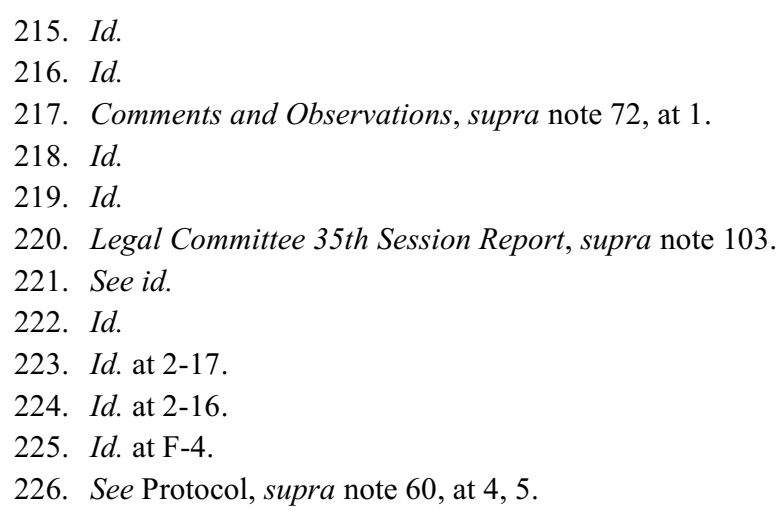


debated items at the Conference. ${ }^{227}$ There were various views expressed regarding whether or not the Protocol should include a list of offences. ${ }^{228}$ Some delegations thought it would strengthen the Convention, while others were completely opposed to the inclusion of an actual list. ${ }^{229}$ The delegations that supported the inclusion of a list debated whether it should be a generic list or a list that addressed only the most serious offences. ${ }^{230}$

The Sub-Committee was unable to agree on which offences should be included in the list, so instead of proposing a list offences, it was decided Article 15 should instead describe impermissible conduct and specific offences could then just be analyzed under the banned conduct. ${ }^{231}$ One reason for not establishing an actual list was due to the need for safeguard provisions in exceptional situations, such as military activities. ${ }^{232}$ Several delegations opposed Article 15 only covering conduct because it overlapped with preexisting conventions and it would "not achieve international uniformity" in regards to the variety of criminal laws across the globe. The Chairman continued to have the draft revised due to the lack of consensus among the delegations. ${ }^{233}$

The Report by the Friends of the Chairman stated the one main consensus that could be included was the reference to any assault upon a crewmember because of its large safety impact on civil aviation. ${ }^{234}$ The other type of conduct described within Article 15 was the refusal to follow an instruction from the aircraft Commander. ${ }^{235}$ Although the Report stated that members of the group were tempted to list explicitly six offences, they decided against it due to not wanting to tell States how to handle their national legislation. ${ }^{236}$ These two types of conduct were aimed at encouraging States to prosecute unruly offences, both types encompassing most imaginable unruly passenger offences. ${ }^{237}$

In regards to the list of offences, Germany argued for proportionality holding that "mere inconveniences and disturbances" did not fit under its criminally sanctionable laws. ${ }^{238}$ Under the disobeying of a Commander's orders category, Germany opposed criminally sanctioning a person who refused to follow a Commander's orders only for the safety of property. ${ }^{239}$ No other States seemed to agree with the removal of property under this type of conduct. ${ }^{240}$

227. See Legal Committee 35th Session Report, supra note 103, at 2-6, 2-7.

228. Id.

229. Id. at 2-7, 2-8.

230. $I d$.

231. See id. at 2-6, 2-7.

232. Id. at 2-7.

233. Id. at 2-9.

234. Id. at $\mathrm{D}-2$.

235. Id.

236. Id at 2-13.

237. Id. at D-3.

238. Germany Doc. No. 8 , supra note 88 , at 4 .

239. $I d$.

240. Id. 
Both ALADA and Indonesia preferred States be required rather than encouraged to prosecute offences falling under the prohibited conduct. ${ }^{241}$ IATA supported the inclusion of a list of offences because classifying conduct as criminal changes from State to State and it may be difficult for police in each State to understand how to charge unruly individuals according to domestic laws. ${ }^{242}$ IATA also asked for an actual definition of a criminal offence to be included in the Protocol and although not explicitly a definition, Article 15 gave a broad view of what could be classified as an offence. ${ }^{243}$

Indonesia explained the ICAO Circular 288 already included a list of offences of unruly passengers and it would be good for ICAO to update this list, which ended up being the Protocol's solution to this issue. ${ }^{244}$ Rather than the inclusion of a list in the Protocol, the Conference decided to request ICAO update its Circular 288 list of offences. ${ }^{245}$ The Report of the Resolution Group described the requested update as a means "to serve as a guide for the purpose of facilitating States to deal with offences and other acts constituting unruly or disruptive behavior on board civil aircraft." ${ }^{246}$ The Resolution Group explained Circular 288 was needed to help determine exactly what "unruly behavior" entails and without an updated list, States might not be able to deal with smaller incidents effectively under their national laws while attempting to follow unclear international policy. ${ }^{247}$

The Report of the Drafting Committee did broaden the scope of prosecution for the prohibited types of conduct beyond only criminal and administrative by adding in the phrase "any other forms of legal proceedings" to Article $15 .{ }^{248}$ Due to the decision to not include a specific list of offences, the decision was made to urge ICAO to update its list of offences under Circular 288 with a more detailed list that also follows the new Protocol to the Convention. ${ }^{249}$

\section{F. Additional Views on Changing the Protocol}

There were many issues the delegates hoped would be solved within the

241. Latin Am. Ass'n of Aeronautical \& Space Law, supra note 48, at 4; Authority in Handling Offences, supra note 200, at 3.

242. Int'l Air Transp. Ass'n, Comments on List of Offences, DCTC Doc. No. 19 (Mar. 13,

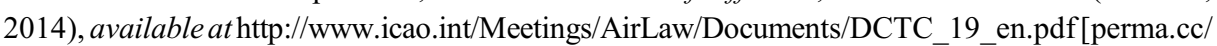
S4FP-QVZ2].

243. Id.; Protocol, supra note 60, at 5 .

244. Authority in Handling Offences, supra note 200, at 1; Protocol, supra note 60, at 5.

245. Int'l Conference on Air Law, Report of the Resolution Group, DCTC Doc. No. 32 (Apr. 2, 2014), available at http://www.icao.int/Meetings/AirLaw/Documents/DCTC_32_en.pdf [perma.cc/DLD5-JZPC].

246. $I d$.

247. Id.

248. Report of the Drafting Committee, supra note 80, at 5.

249. Final Act, supra note 51, at 6. 
Protocol and much debate took place on various issues during the Conference. ${ }^{250}$ Many States gave additional opinions regarding the actual obligations of the aircraft Commander when an unruly passenger event takes place aboard his aircraft. ${ }^{251}$ According to the document submitted by the United Arab of Emirates, IATA, the International Federation of Air Line Pilot's Associations (IFALPA), and the International Union of Aerospace Insurers (IUAI), nearly every delegation had an opinion regarding the explanation and analysis of the objective reasonableness standard for Commanders' actions and any potential liability for these actions under Articles 6 and $10 .^{252}$ The extradition of a detained, unruly passenger was also a topic of debate. ${ }^{253}$ Finally, the last key issue discussed was the right to seek recovery from an unruly passenger for the damages suffered due to his or her conduct. ${ }^{254}$

\section{WAS THIS A MisSED OPPORTUNITY?}

After much debate and deliberation, the final version of the Protocol was complete. This Protocol was combined with the Convention to form the modernized Tokyo Convention, also known as Montreal 2014. ${ }^{255}$ Due to the fact there were eighty-eight States represented at the Conference, many people assumed this international treaty would be quickly ratified, but that has not been the case. So far only twenty-nine States have signed the Protocol and only one has ratified it. ${ }^{256}$ The States that have signed the Protocol are Angola, Benin, Brazil, Burkina Faso, Burundi, Cabo Verde, Cambodia, China, Congo, Cote d'Ivoire, Dominican Republic, Gabon, India, Jordan, Kuwait, Lesotho, Madagascar, Mali, Mexico, Nepal, Niger, Nigeria, Paraguay, Senegal, Sierra Leone, Spain, Sudan, Togo, and Turkey. ${ }^{257}$ Fiji has accepted the Protocol and Congo has ratified it. ${ }^{258}$ According to Article 18, the Protocol will not go into force until two months after the twenty-second State has submitted the "instrument of ratification, acceptance, approval or accession with the Depositary. ${ }^{, 259}$ One must then ask why other States have not signed the treaty and

250. See generally Protocol, supra note 60.

251. See generally Japan Doc. No. 10, supra note 201; NZ Doc. No. 9, supra note 99.

252. Amendment to Article 10, supra note 189, at 1-2.

253. Latin Am. Ass'n of Aeronautical \& Space Law, supra note 48, at 4; IATA Doc. No. 20, supra note 90, at 1-2; Note of the Secretariat, supra note 53.

254. Diplomatic Conference, supra note 55, at 6; Draft Text, supra note 54, at 4; IATA Doc. No. 18, supra note 83, at 2; Int'1 Air Transp. Ass'n, Comments on the Right of Recourse, DCTC Doc. No. 22 (Mar. 13, 2014), available at http://www.icao.int/Meetings/AirLaw/Documents/ DCTC_22_en.pdf[perma.cc/6JZX-5WDG]; Legal Committee 35th Session Report, supra note 103, at 24-25; Note of the Secretariat, supra note 53.

255. See generally Final Act, supra note 51.

256. Protocol, supra note 60.

257. $I d$.

258. Id.

259. Id. 
whether all of the work that went into the Protocol was really a missed opportunity to considerably improve international aviation law with modern solutions and whether there were too many things left out of the Protocol, which caused States to doubt the benefits that would come from signing it.

\section{A. Jurisdictions}

Although the Protocol did make vast improvements on the topic of jurisdictions, there were still issues left unsettled. ${ }^{260}$ Qatar did not support the jurisdictions the Legal Committee had proposed because they did not solve the current issues. Qatar did not gain support on its view and the State of Landing along with the State of the Operator were added to the Protocol, while the State of Registration had previously been included in the Convention. ${ }^{261}$ The issues Qatar raised support the conclusion the jurisdictional provisions within the Protocol should have been further clarified ${ }^{262}$ First, the Protocol did not explain how jurisdictions at conflict were to be resolved, such as who would win if the State of Landing and the State of Registration disagreed about who should exercise jurisdiction and prosecute the case. ${ }^{263}$ A very intense conflict could arise when the national State of the offender and the national State of the victim are in conflict. ${ }^{264}$ In this case, should a completely new jurisdiction take over in order to ensure due process or would the prevailing jurisdiction be sufficient? Third, what does the phrase in Article 3 "measures as may be necessary" entail? ${ }^{265}$ In other words, what steps does each State need to take to exercise jurisdiction? Qatar argued as this phrase was written within Article 3, necessary force could be used to exercise jurisdiction and it would technically be allowed under the Protocol. ${ }^{266}$ Qatar addressed areas where the Convention left gaps, especially the gap in the opportunity to prevent further conflicts between jurisdiction, which could have been solved with more definitions and a provision actually outlining the process to take when there are conflicting jurisdictions. ${ }^{267}$

The Working Group on Jurisdiction posed three main questions when addressing the proportionality issue; however, it never directly answered any of them. ${ }^{268}$

[1] Does the act or offence warrant potential inconvenience to alleged offender, passengers and crew of being involved in a criminal or administrative process which may be conducted far from their home?

260. See generally id.

261. Id. at 3 .

262. $I d$.

263. Id.

264. Id.

265. Id.

266. Id.

267. Id.

268. Jurisdiction Report, supra note 122, at 3. 
[2] Is the expense and difficulty of affording the offender the rights to fair treatments required by international law (translation etc.) commensurate with the scale of the wrong alleged to have been committed?

[3] What is the strength of justification for departing from the normally accepted principle that extra-territorial jurisdiction for criminal offences should only be exercised in exceptional cases? ${ }^{269}$

In the revised Report of the Working Group on Jurisdiction, a dual-criminality test was considered, which stated, "[i]n exercising its jurisdiction as State of Landing, a State shall consider whether the offence or act in question is generally an offence in other States [and the security of the penalties that generally apply]. ${ }^{270}$ Although this dual-criminality test was not added into the Final Protocol, the final version of Article 3.2ter did allow a similar test simply between the State of Landing and State of the Operator. ${ }^{271}$ Due to the fact that the Working Group of Jurisdiction did not want to reopen the mandatory jurisdiction issue, how to handle the issue when the State's prosecutors do not have the discretion to prosecute all possible offences within this new obligation was left unresolved. ${ }^{272}$

\section{B. IFSOS}

The United States did not win the argument that Option One of Article 6 be adopted. ${ }^{273}$ Although it addressed the issue of the Commander having complete authority over the aircraft, the Protocol failed to address what should be done if the Commander is unable to handle the situation or is in some way incapacitated. ${ }^{274}$ Although allowing passengers and IFSOs to take reasonable action against a threat, the new Convention missed the opportunity of adding in the very useful tool of IFSOs' skills that could likely prevent offences or minimize the effects that come from these offences. ${ }^{275} \mathrm{~W}$ ith more than forty States having IFSO programs and the likelihood more States will create these programs, the Protocol did not sufficiently deal with the issue of using IFSOs on international flights. ${ }^{276}$ The Commander may have the overall authority; however, the Protocol does not address how a disagreement between an IFSO and a Commander should be handled. ${ }^{277}$ When Option Two was adopted, potential disagreements should have been specifically addressed to limit the IFSOs duties

269. Id.

270. Id.

271. Protocol, supra note 60 , at 3.

272. Jurisdiction Report, supra note 122, at 3.

273. Protocol, supra note 60 , at 4.

274. Id.

275. Id.

276. See generally U.S. Doc. No. 7, supra note 170.

277. Id. 
adequately since that is why many of the States supported the second option. The Convention seemed simply to ignore the Philippines beneficial solution to potential disagreements by adding in a phrase to show the chain of command explicitly. ${ }^{278}$ The inclusion of such a phrase would have easily addressed many potential conflicts that could arise during an unruly passenger event in the future.

\section{List of Offences}

The Protocol did not contain a list of offences, but rather it included the two types of unacceptable behavior and then requested that ICAO update its Circular 288 with a more detailed and modernized list of offences. ${ }^{279}$ For the States who supported the list of offences within the Protocol, this probably seems as though the buck was simply passed to ICAO and if the Circular 288 were to be updated it would not be in the near future. As of December 2014, ICAO had not updated the Circular 288 and there has been no more direction given as to what exact offences should be classified as unruly behavior. The Conference was the chance to solve this pressing issue with many States in the same place, but instead the decision was made not to deal with it and to push it off for future debate.

\section{Ability to Obtain Damages from the Unruly Passenger}

Although Article 18 bis is only one short sentence, it has the ability to have a great impact on the future of civil aviation law. ${ }^{280}$ This provision states, "[n]othing in this Convention shall preclude any right to seek the recovery, under national law, of damages incurred, from a person disembarked or delivered pursuant to Article 8 or 9 respectively." 281 It does not explain who is precluded from seeking recovery. ${ }^{282}$ The draft text of this provision had clarified that only the aircraft operator could recover damages from the offender, but this version was not added into the Protocol. ${ }^{283}$ How the provision currently reads it seems to mean that anyone can seek recovery from a disembarked unruly passenger. ${ }^{284}$ The Protocol should have further explained whether it meant solely the airlines could recover damages due to the diversion and delays and passengers could then gain damages from the airline's recovery or whether each person or company affected by the offence could seek to recover damages. According to the IATA survey, approximately $39.62 \%$ of respondents had to divert a flight due to an unruly passenger offence within a twelve-month period. ${ }^{285}$ Only $10.87 \%$ were actually able to recover from the offender all or a substantial amount of costs pertaining to the diversion, while the majority of other airlines stated they were rarely

278. Philippines Doc. No. 16, supra note 198.

279. Protocol, supra note 60 , at 3.

280. Id.

281. Id. at 6 .

282. Id.

283. Legal Committee 35th Session Report, supra note 103, at 24-25.

284. Id.

285. Int'l Air Transp. Ass'n, supra note 36, at 3. 
successful in recovering any costs from the offender. ${ }^{286}$ The two most cited reasons for not being able to recover these costs were the offender's inability to pay and the legal issues surrounding the event. ${ }^{287}$ This provision was left too broad and the consequences of its wording could have an interesting effect on anyone involved in an unruly passenger event.

\section{E. General Overlooked Issues}

Although IATA's STEADS Report identified alcohol as the lead contributing factor in unruly passenger events, the Convention did not address whether alcohol should be banned on all international flights or whether an already intoxicated person should not be allowed to board the aircraft. ${ }^{288}$ This is not a contributing factor that should be ignored because it seems that many of the offences would not have occurred without it. Even if alcohol was not completely banned, there could be a limitation on alcoholic beverages provision added. Alcohol possibly was not addressed due to the very specific nature of this contributing factor; however, it is not one that should be overlooked.

Throughout the Protocol, the aircraft Commander is held to a reasonableness standard for any actions he or she may take against an unruly passenger ${ }^{289} \mathrm{~A}$ publication by the law firm Morrison \& Forrester states, "[i]t would have been helpful to airlines if the Protocol clarified that this was a standard deferential to the aircraft commander's judgment and that actions not 'arbitrary or capricious' are considered reasonable under the Convention." ${ }^{290}$ Adding this clarification would aid in any trial for the prosecution of an unruly behavior offence where the defense raises the reasonableness of the Commander's actions. ${ }^{291}$ Therefore, the Protocol did not go far enough when deciding the standard for the Commander's actions and due to this insufficient standard, more issues are likely to arise, especially during the prosecution of any unruly behavior offence.

The issue of making the Protocol gender neutral arose a few times throughout the Conference. ${ }^{292}$ The suggestion was to add "or her" every place where the term "him" was used, or as New Zealand suggested, the use of "she" along with the use of the word "he." ${ }^{293}$ This was never added and there was no explanation as to

286. Id.

287. $I d$.

288. Id.

289. See generally Protocol, supra note 60.

290. William V. O'Connor, Ellen Nudelman Adler \& Joanna Simon, Unruly Passengers Beware: ICAO Delivers Montreal Protocol 2014 To Enhance Enforcement Measures Against Unruly Passengers, MORRISON \& FORRESTER LLP, http://www.mondaq.com/unitedstates/x/ 311196/Aviation/Unruly+Passengers+Beware+ICAO+Delivers+Montreal+Protocol+2014+To+ Enhance+Enforcement+Measures + Against+Unruly+Passengers [perma.cc/LYB7-Q3E5] (last updated Mar. 30, 2016).

291. Id.

292. NZ Doc. No. 9, supra note 99, at 2; Note of the Secretariat, supra note 53.

293. Id. 
why this simple issue was left untouched.

IATA created a list of provisions to strengthen the Protocol and provide further clarification on how to handle unruly passenger offences. ${ }^{294}$ First, IATA suggested having a Passenger Notification Warning Card distributed to a passenger whose behavior was beginning to be unacceptable. ${ }^{295}$ The card would explain the aircraft Commander's powers under the Convention and the consequences for continuing this type of behavior. ${ }^{296}$

The second suggestion was that briefing cards were to be given to the local law enforcement in the State of Landing that explained the Commander's powers, especially in regards to disembarkation and delivery of an unruly passenger to the local authorities. ${ }^{297}$ The briefing card would also be used to help inform law enforcement on how to handle the situation properly under the provisions of the Convention. ${ }^{298}$

One potential problem not mentioned in regards to the first or second suggestions was if this suggestion was added, every aircraft would need to be equipped with cards in every language so no one could claim they were unable to understand it due to a language barrier.

Third, an Unruly Passenger Incident Form should be completed by the airlines after the occurrence of an unruly passenger offence to document any relevant information and preserve any evidence. ${ }^{299}$ IATA also suggested there should be a recorded procedure on how airlines should properly deal with authorities and work together to achieve prosecution of the offence. ${ }^{300}$ Under these policies, airlines could possibly be required to pay their employees just as if they were on duty for any time spent meeting with police or aiding in the prosecution. ${ }^{301}$ IATA, however, did not address the financial impact on airlines from having to incur even more costs related to the offence.

Although many of these issues were addressed at the Conference it is unclear why the Protocol never resolved them. The Protocol's purpose was to modernize the Convention to limit the amount of offences taking place on international aircrafts, but it failed to fulfill this purpose.

\section{CONCLUSION}

Unfortunately, this Protocol, along with other treaties and amendments, has not created a universally supported system of international civil aviation laws. ${ }^{302}$ Without this system, a powerful deterrent is lacking in regards to people believing

294. O'Connor et al., supra note 290.

295. Int'l Air Transp. Ass'n, supra note 36, at 3.

296. Id.

297. Id.

298. Id.

299. Id.

300. Id.

301. Id.

302. Serrao, PowerPoint Presentation, supra note 2. 
prosecution will occur for unruly offences taken against the international aviation community. ${ }^{303}$ The main way to deter future offences is through domestic regulations and airport security procedures, which do not reach the same level of deterrent that could exist under a uniform international system. ${ }^{304}$ It is likely that the rise in unruly offences and terrorism will continue to target civil aviation until a true deterrent is established. ${ }^{305}$

The private sector does not view the Protocol as going far enough to help solve the problem of the increasing number of unruly passenger events in flight. ${ }^{306}$ As shown by the lack of signatures and ratifications, most States seem to agree with the private sector that the Protocol did not fulfill the objectives of the Conference and left too many issues undecided. ${ }^{307}$ Overall, it is unlikely that this Protocol will be signed or ratified by more States in the near future unless ICAO helps to clarify and address the missing pieces within this giant puzzle.

303. Id.

304. Id.

305. Id.

306. Id.

307. See generally Protocol, supra note 60. 